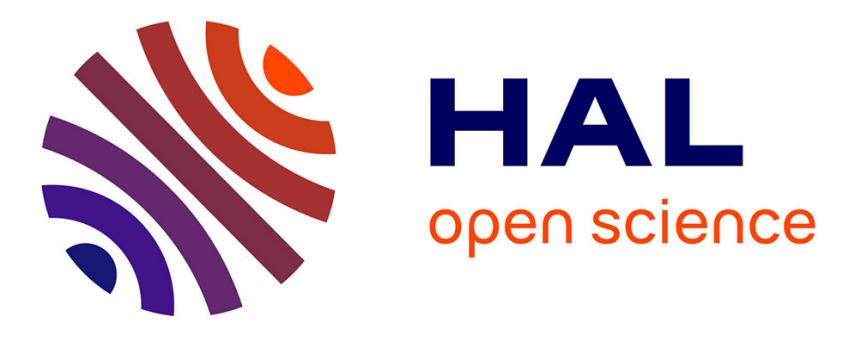

\title{
Describing and locating cropping systems on a regional scale. A review
}

Delphine Leenhardt, Frédérique Angevin, Anne Biarnès, Nathalie Colbach, Catherine Mignolet

\section{- To cite this version:}

Delphine Leenhardt, Frédérique Angevin, Anne Biarnès, Nathalie Colbach, Catherine Mignolet. Describing and locating cropping systems on a regional scale. A review: A review. Agronomy for Sustainable Development, 2010, 30 (1), pp.131 - 138. 10.1051/agro/2009002 . hal-00886439

\section{HAL Id: hal-00886439 \\ https://hal.science/hal-00886439}

Submitted on 1 Jan 2010

HAL is a multi-disciplinary open access archive for the deposit and dissemination of scientific research documents, whether they are published or not. The documents may come from teaching and research institutions in France or abroad, or from public or private research centers
L'archive ouverte pluridisciplinaire HAL, est destinée au dépôt et à la diffusion de documents scientifiques de niveau recherche, publiés ou non, émanant des établissements d'enseignement et de recherche français ou étrangers, des laboratoires publics ou privés. 


\title{
Describing and locating cropping systems on a regional scale. A review
}

\author{
Delphine LEENHARdT ${ }^{*}$, Frédérique ANGEvin ${ }^{2}$, Anne BIARnÈS $^{3}$, Nathalie COLBACH $^{4}$, Catherine MignOLET $^{5}$ \\ ${ }^{1}$ INRA, UMR1248 - AGIR (Agrosystèmes et développement territorial), BP 52627, 31326 Castanet Tolosan Cedex, France \\ 2 INRA, UAR1240 Eco-Innov, BP 01, 78850 Thiverval Grignon, France \\ ${ }^{3}$ IRD, UMR1221 LISAH, 2 place Viala, 34060 Montpellier, France \\ ${ }^{4}$ INRA, UMR1210 Biologie et Gestion des Adventices, 17 rue Sully, BP 86510, 21065 Dijon Cedex, France \\ ${ }^{5}$ INRA, UR55 SAD-Mirecourt, 662 avenue Louis Buffet, 88500 Mirecourt, France
}

(Accepted 9 January 2009)

\begin{abstract}
At regional scale issues such as diffuse pollution, water scarcity and pollen transfer are closely related to the diversity and location of cropping systems because agriculture interacts with many other activities. Although sustainable land use solutions for territorial development and natural resource management are needed, very few agro-environmental studies account for both the coherence and the spatial variability of cropping systems. The originality of this article is to review methods that describe and locate cropping systems within large areas. We mainly based our analysis on four case studies using the concept of cropping systems on a regional scale, but differing in their objectives and extents. We found that describing and locating cropping systems in space meets not only decision-making stakes but also a scientific stake that allows multi-simulations over large areas when models require cropping system information. Simulation models are indeed necessary when the study aims at estimating cropping system externalities. Then, the involved process determines the extent, and the model determines the support unit, unless socio-economic considerations prevail. In this case, as well as when no model is involved, it is often considerations related to stakeholders that determine extent and support unit choices. On a regional scale, the cropping system must be described by only a few variables whose selection depends on the study objective and the involved processes. Collecting cropping system information for all support units is often simplified by identifying determining factors of cropping systems. However, obtaining deterministic relations between easily accessible factors and cropping system variables is not always possible, and sometime accessing modalities of determining factors for all support units is also difficult. We found that describing and locating cropping systems relied very much on expertise and detailed survey data. The development of land management practice monitoring would facilitate this description work.
\end{abstract}

agricultural practices / spatial distribution / modelling / cropping system / scale change / environmental impact

\section{INTRODUCTION}

On a regional scale, where agriculture interacts with many other activities, and where various farmers and various cropping systems interact together, many management problems are closely related to the nature, diversity and location of cropping systems. For example, to adjust the quality of cereal lots to millers' requirements, the cooperative needs to know the distribution of the performance, e.g. yield and protein content, of the collected crop over its collect basin (Le Bail, 2005). This results from the characteristics of the cropping systems such as preceding crop, sowing dates, varieties and fertilisation. For agricultural planning of a country or to assist market-

* Corresponding author:

Delphine.Burger-Leenhardt@ toulouse.inra.fr ing decisions for farmers and grain traders, it is also necessary to predict crop or forage yield on a national or regional basis (e.g. Lal et al., 1993; Rosenthal et al., 1998; Chipanshi et al., 1999; Donet, 1999; Faivre et al., 2000; Yun, 2003). Calculating water requirements for agriculture within the area served by a water provider requires knowing where, in terms of soil and weather conditions, irrigated cropping systems are located, and to distinguish whether these cropping systems are intensively irrigated or not (e.g. Sousa and Santos Pereira, 1999; Heinemann et al., 2002; Leenhardt et al., 2004). Similarly, an accurate knowledge of cropping systems is needed to estimate nitrogen or pesticide pollution of streams or groundwater from agricultural land (Beaujouan et al., 2001; Gomez and Ledoux, 2001; Louchart et al., 2001; Biarnès et Colin, 2006) or to evaluate the risk of occurrence of genetically-modified (GM) seeds in non-GM harvests (Colbach, 2008; Angevin et al., 2008). 
Table I. Short description of the four case studies on which the analysis of the article is mainly based, with their references and, in italics, related references.

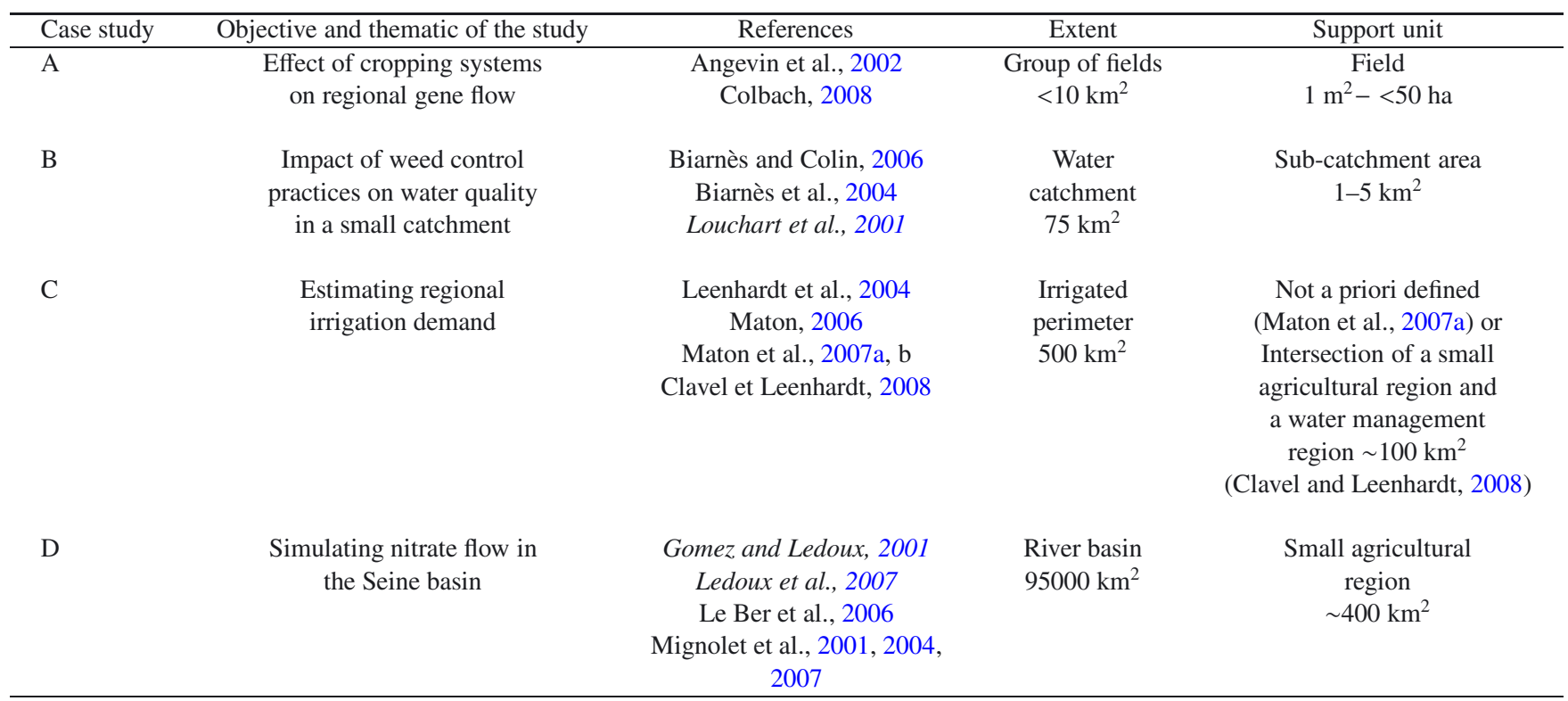

The existence of dispersal processes such as water runoff and pollen dispersal may require, in addition, knowing the exact and relative locations of cropping systems. It may also require knowing the location of semi-natural areas such as grass strips and roadsides because a cropping system in one location can reduce or increase the effect of a neighbouring cropping system. For instance, herbicide runoff from a field may be reduced by a grass strip; GM propagation from a GM field will be increased if fields of similar GM cropping systems are surrounding it.

This rapid overview shows that information regarding crops and agricultural practices is required for solving many agrienvironmental management problems. Accounting for the strong links that can exist between technical operations, between successive crops, and between crops and technical operations, can considerably improve decision-making by evoking more sustainable management decisions. Describing and locating cropping systems in space thus meets a public decisionmaking need.

This outlook article aims at presenting how cropping systems can be described and located within large and/or heterogeneous areas including a great number of fields, and therefore likely to present a great variability of cropping systems. For this purpose, it is based on four groups of studies covering a wide range of agri-environmental problems and extents (Tab. I). They all use the concept of the cropping system but developed the necessary simplifications to account for the spatial variability of cropping systems on a regional scale. First, we present the concept of the cropping system and its classical use on a regional scale. Then, we present the objectives for which it is necessary to describe and locate cropping systems, which lead us to specify when environmental process models are used. In a second section, we highlight some scale issues.
The third section states the problem of the description of cropping systems, in particular the choice of the variables to use. The collection of these variables at the required resolution is the subject of the last section, which distinguishes the direct collection of these variables from an indirect way that involves identifying and collecting determining factors of the cropping systems.

\section{USING THE CONCEPT OF CROPPING SYSTEMS ON A REGIONAL SCALE}

The concept of the cropping system used in this article was developed in the framework of traditional French agronomic research. It was precisely defined by Sebillotte (1974), for an area managed homogeneously, as "the crops, their succession order and the crop management systems associated with each crop". The cropping system was thus considered as a sub-system of the complex land use system, its typical spatial scale being the field plot. On such a scale, Meynard et al. (2001) insisted on the temporal coherence of the cropping system: the crop management system corresponds to a logical and coordinated succession of actions; the various technical choices made within a given cropping system are not independent. Later, Veldkamp et al. (2001) showed that agronomic research could also be relevant at the landscape level, and, on such scale, Benoît and Papy (1998) and Jouve (2006) noticed that crop successions and crop management systems did not result from a random process but were the result of logic and decision processes. These authors highlighted the spatial coherence of cropping systems.

Nevertheless, the concept of the cropping system is rarely emphasised on scales greater than the field. The main reason is probably that information related to cropping systems 
is lacking or difficult to collect when a great number of fields is concerned. Therefore, the description of agricultural activities and land use is most often very simplified on such a "regional"1 scale. Simplification often leads to neglecting the concept of the cropping system. A first simplification consists of restricting the concept of the cropping system to its primary characteristic, i.e. the knowledge of the cultivated species, as noted by Jouve (2006). This schematisation is common in the remote-sensing approaches used to describe land use data for environmental issues (Martin et al., 2006). The description of agricultural land cover is usually restricted to soil occupancy, e.g. cultivated areas, forests, grassland and built-up areas; and to main crop groups such as annual versus permanent crops and, at the most, crop species such as maize and wheat (Verburg and Veldkamp, 2001). Details on crop management systems and crop successions are usually omitted. A second level of simplification consists of describing the crop management system as a fixed and uniform sequence of technical operations. This sequence can either consist of average practices (Moen et al., 1994) or correspond to recommended management guidelines (Yun, 2003). The spatial variability in crop management systems is often neglected and the same recommended or averaged practices are used for a large part or the whole spatial extent. The temporal coherence of the management system is also often limited: crop management systems are expressed as a fixed calendar of technical operations. This second level of schematisation is frequently adopted in optimisation studies which aim at rationalising crop acreage over a region to reach defined targets. Each crop or crop rotation is associated with a fixed sequence of technical operations which allows the calculation of various indicators such as input costs or externalities (de Juan et al., 1999; Nordblom et al., 2006; Reca et al., 2001; Stoorvogel, 1995).

However, Barson and Lesslie (2004) and Leteinturier et al. (2006) note that detailing crop management systems and crop successions can be of importance in many environmental perspectives and Stomph et al. (1994) specify that a quantitative description of land use practices is necessary. This is why some studies, e.g. those reported in Table I, use the concept of the cropping system to describe and locate agricultural activities over large areas.

\section{OBJECTIVES OF DESCRIBING AND LOCATING CROPPING SYSTEMS ON A REGIONAL SCALE}

This description of cropping systems may directly provide the solution to the management problem, or may only be a means to obtain this solution. For instance, to estimate the impact of land use on water resource use, the key is to know the distribution of irrigations during summer, i.e. to know the area cultivated with irrigated crops and the amount of water

\footnotetext{
1 We use here the word "region" to refer to any area so large or heterogeneous that it includes a great number of fields impossible to survey. In this article, a "region" could be a small area of less than $10 \mathrm{~km}^{2}$ with many small fields, as well as a very big river catchment $\left(\sim 100000 \mathrm{~km}^{2}\right)$.
}

applied during the season (Leenhardt et al., 2004). However, most agri-environmental problems are relative to the impact of cropping systems on their environment. They deal with externalities of cropping systems, e.g. nitrate loss and pollen dispersal. Externalities are usually simulated by models using cropping system information as input. Depending on the physical processes involved, two modelling approaches exist. The first consists of spatially-explicit modelling to represent flows within the area under consideration (Dunning et al., 1995). The second consists of running a 1-D model such as a crop model at every point, or a sample of points, of the area (Hartkamp et al., 2004). For spatially-explicit models the exact location of cropping systems is required, while for 1D models only the relative area grown with each crop $\times$ management combination for each soil $\times$ weather condition is necessary. Both modelling approaches require high-resolution land use data (Verburg et al., 2002). For instance, to estimate water pollution by nitrate leaching, it is necessary to model the nitrogen use by crops, nitrogen transformation in the soil, and vertical and lateral water flows (e.g. Beaujouan et al., 2001; Gomez and Ledoux, 2001). Such a modelling approach needs input data on the crops sown and their location, their sowing dates, that determine the periods of crop growth and water and nutrient uptake, and the periods of fertiliser and water supply. Describing and locating cropping systems in space thus meets a scientific need. It makes it possible to use on a regional scale models developed on a local scale (Faivre et al., 2004; Leenhardt et al., 2006).

We can distinguish three different types of issues where cropping system information is needed. First, diagnostic studies for evaluating the impact of land use and land cover on the environment or on natural resources require data on existing or past land use, and therefore, on existing or past cropping system distribution. Second, scenario simulation approaches also evaluate impacts, but those of proposed prospective rather than actual situations. Therefore, the required data not only concerns the current distribution of land use but also options and constraints for modifications in the current practices. Since prospective situations are usually compared with the present or a former situation, scenario studies are often associated with diagnostic studies. The last type aims at identifying optimal land use for a given economic, environmental or multi-criteria objective. Optimal land use, or even optimal cropping system distribution, is determined by iterative choice and evaluation algorithms and two kinds of data are therefore required. First, a set of cropping systems is necessary to initiate the run. This set can correspond to the current situation, but this is not compulsory. Second, a set of alternative cropping systems, or a range of cropping system components to be combined during evaluation, must be specified. As in scenario simulation, the search for optimal solutions belongs to a planning approach and aims at determining the spatial organisation of cropping systems to reach desirable objectives.

To summarise, describing and locating cropping systems is used for diagnostic or scenario studies, either because cropping systems are directly targeted or because cropping system information is required as input for an environmental model. Describing and locating cropping systems in space allows 
multi-simulations on a regional scale. Describing and locating cropping systems can also serve to define the base situation and cropping system basket from which an optimal land use can be calculated to satisfy given objective functions.

\section{SCALE ISSUES}

Up to this point the word "scale" has been used in its colloquial sense. It covers, in fact, both the "extent", i.e. the area of interest of the study, and the "support", comprising a finite number of smaller areas, the "support units", on which information is collected. Support units can cover integrally or not the extent; the ratio "support"/"extent" is called the coverage (Bierkens et al., 2000; Faivre et al., 2004).

The analysis of various case studies, and particularly those reported in Table I, shows that the extent is most often determined by the processes involved, but also by the context and objectives of the study. For instance, when the studied environmental problem requires accounting for physical flows conditioned by topographical features, e.g. modelling water flows for calculating diffuse pollution, the extent corresponds to a space with natural landscape delimitations, e.g. a stream or a river catchment area (cases B \& D, Tab. I). In addition, the resulting pollution can be more easily measured at the outlet of the catchment, which also justifies choosing as the extent a whole catchment. In other situations, the process involved is not the only factor that determines the extent of the study. It is particularly the case when the study is conducted with a socio-economic partner who often influences the choice of the extent. For instance, in a study dealing with harvest purity (case A), the extent was partly determined by the expected impact of the studied process, here the area of pollen dissemination. Similarly, Gomez and Ledoux (2001) studied nitrate pollution for the whole Seine basin, rather than in a small catchment area, because it was the area of the water manager who was both partner and recipient of the study (case D). In the regional irrigation demand study (case C), no physical dispersal or diffusion process was involved. Therefore, the extent was entirely determined by management considerations and corresponded to a space delimitated by installations, the irrigated area, which is the decision unit for water allocation decisions.

Once the extent is determined, it must be broken down into support units, where data on the cropping system is provided. The choice of support units often depends on the process involved and the model used to simulate it.

When dispersal and other spatial processes have to be considered, their nature and impact distance are often the key factor for choosing the support units. For example, when output flows from the cropping systems convey water and other elements that may influence surrounding crops (e.g. gene flow, herbicide runoff), it is important to simulate these lateral flows with spatially-explicit models, and to account for the spatial arrangement of crops and cropping systems. The field, which can be considered as a homogeneous unit regarding the crop and its management, naturally becomes the support unit for providing data on the cropping system, as well as the simulation unit (case A) Some models require as a simulation unit a sub-catchment $\left(1-5 \mathrm{~km}^{2}\right)$, which then becomes the support unit of cropping system information. However, when the extent is very large relative to the size of fields or small sub-catchments, spatial processes may be negligible compared with other processes. For instance, Ledoux et al. (2007) neglected lateral flows between fields because they assumed that these lateral flows did not change the overall diffuse pollution. Neglecting spatial processes led to using a 1-D model to simulate "vertical" nitrate leaching. The only constraint for running these 1-D models on the studied area is to define spatial simulation units that are homogeneous combinations of the variables used as model input (generally variables describing the soil, the weather and the cropping system). These homogeneous soil-climate-cropping system combinations should naturally become the support units on which information regarding the cropping system has to be provided. This is, though, not always possible when extents are very large (case D) because the number of simulation units may be excessive regarding the computation time (Ledoux et al., 2007). Support units were then chosen a priori because they retrieved correctly the spatial differentiations of cropping systems (Mignolet et al., 2004), and the 1-D model was run on homogeneous simulation units that were then not explicitly located within each support unit. Sometimes, no process model is required and conditions the choice of support units. For example, in case C, the objective of the study is to estimate the regional irrigation demand. This target can be reached by simply aggregating the irrigation demand estimated for each support unit, whatever its size and nature. Thus, in this case, the support unit can be determined a posteriori, with regard to the kinds of indicators used to estimate the spatial distribution of agricultural practices (Maton et al., 2007a), or a priori, with regard to their significance for the various stakeholders concerned with the study (Clavel and Leenhardt, 2008).

To conclude, we note that when the objective of the studies is to estimate externalities of cropping systems a process model is required. Then the process determines the extent and the support unit. When socio-economic considerations prevail, as well as when no model is involved, it is often considerations related to stakeholders which condition extent and support unit choices.

\section{DESCRIBING CROPPING SYSTEMS BY RELEVANT VARIABLES}

Describing a cropping system is a difficult task, even on the field scale. Should all technical operations of the crop management system be characterised? How detailed should this description be? This problem is even greater on a regional scale. Can cropping systems from two different sites be considered as similar? The elements that constitute a cropping system are the crop rotation and the various technical operations of the management system of each crop of the rotation. Which then are the elements to survey in order to describe the main representative cropping systems of a region? 
The necessary cropping system variables must therefore be carefully chosen in relation to the study objective and the analysed processes to optimise the compromise between key variables and data availability. For instance, Colbach (2008), working on spatio-temporal gene flow in oilseed crops and volunteers (case A), showed that it is sufficient to include those cropping system components that significantly influence the two major stages for gene flow, i.e. plant survival and pollen dispersal, and that the remaining techniques such as fungicides or fertiliser, which mostly influence seed production, can be neglected. Similarly, in a study dealing with regional irrigation demand in a region dominated by irrigated maize (case C), Maton (2006) simplified the various cropping systems in irrigated maize to the 3 main elements influencing the total irrigation applied on a maize field, i.e. irrigation management, sowing practice and earliness choice. Such approaches reduce the amount of data to be collected to characterise the cropping systems without neglecting their internal consistency. They also help to simplify the simulation models used in the studies, rendering them thus more robust.

\section{COLLECTING DATA}

Data collection for characterising and locating cropping systems on a regional scale is a real challenge. As a consequence, exhaustive and systematic collection of information about land management practices on the regional scale is only at its early stage, and is most of the time partial and descriptive, with no understanding of the links between technical interventions within crop management systems (BRS, 2006; Mignolet et al., 2007).

Two ways of collecting data to describe cropping systems are possible and not exclusive: the direct way, which aims at collecting information regarding the relevant elements of the cropping systems, and the indirect way, which consists of collecting information about indicators, or determining factors, of the cropping systems. These two ways, and the techniques used, are more or less adequate, depending on whether the cropping system data collection aims at describing existing or past cropping system distributions for elaborating a diagnosis, at building scenarios of cropping systems, or at seeking an optimal cropping system distribution.

\subsection{Direct collection}

Collecting directly the variables that characterise the cropping systems concerns mainly diagnosis studies. Direct data collection by survey requires long and arduous work because of the great number of farms on a regional scale and is thus generally unrealistic (Biarnès et al., 2004). Three main alternative solutions exist. The first is to use remote-sensing techniques to estimate the spatial variability of specific technical interventions, such as sowing dates (Launay and Guérif, 2005). However, some interventions and technical choices are not detectable by remote-sensing, or with difficulty or at high cost. This is the case, for example, for irrigation application dates and amounts or for the choice of cultivar or earliness for a given crop. The second is to make the best use of existing regional databases (e.g. Agricultural census, Ter-Uti-LUCAS database) to provide knowledge on past cropping systems, mostly by using statistical analysis. For example, Mari and Le Ber (2005) developed data-mining techniques to estimate the spatial variability of past crop rotations from such databases (Le Ber et al., 2006). This solution is, however, limited by the nature of variables collected systematically in administrative databases, and by the length and cost of specific surveys that may be conducted to get variables not systematically surveyed by administrations. If, in France, the number of variables collected by the many surveys conducted by the Department of Economical and Statistical Studies $\left(\right.$ SCEES $\left.^{2}\right)$ is huge, the nature and size of the sample used differ from one survey to another, rendering multivariate analyses difficult if not impossible. The last option is to use expert knowledge, as Mignolet et al. (2004) did, to associate a management system with a crop or a crop rotation (case D). However, this option requires long surveys when the extent is large and if the spatial variability is to be taken into account, and the quality of expertise decreases as the survey goes further into the past. Experts can, however, inform not only on past and/or recommended practices, but also provide innovative practices that can be of interest for scenario studies (Lançon et al., 2008).

\subsection{Indirect collection: use of determining factors}

Despite the reduced number of variables to be collected for describing a cropping system, these variables may not be included in available databases, or not at a sufficient resolution for characterising past cropping systems on all support units. An indirect way to determine and locate the cropping systems within the extent is to identify the factors involved in their spatial organisation, e.g. soil depth and water availability for choosing crop species or soil type for choosing tillage strategies. These "determining factors" of the cropping system are often easier to collect on the support units and are thus used as indicators of current or past cropping systems for diagnosis studies. For scenario studies, the use of determining factors seems compulsory since it is not possible to collect cropping system data for future or hypothetical context changes. Knowing which factors determine the cropping system and estimating the evolution of such factors through modelling or expertise contributes to estimating and proposing cropping systems for future or hypothetical conditions. For instance, when cropping systems are determined by farming system or farm structure (case A - Angevin et al., 2002 - and C - Maton et al., 2007b), it is possible to deduce the distribution of cropping systems within a region from economic scenario analyses that produce changes in farm-type distributions (Zimmermann et al., 2006). Similarly, when cropping system elements can be related to climatic indicators (e.g. irrigation amounts and dates - Leenhardt et al. 2004, or sowing dates - Maton et al. 2007a), the use of climate change scenarios

\footnotetext{
${ }^{2}$ Service Central d'Études Économiques et Statistiques
} 
(e.g. long-term emission scenarios developed by the Intergovernmental Panel on Climate Change - IPCC, 2007) can provide indications on the way cropping systems over a region may change. Determining factors are also used in optimisation studies: they represent the constraints that should be satisfied when calculating the optimal crop distribution for a given objective function. For example, Rounsevell et al. (2003) consider that various variables determine (or constrain) the choice of cropping systems: the availability of machinery and labour on the farm, the existence of a sugar factory and regional sugar beet quotas, the previous crops, the soil and the climate, the latter two variables conditioning the workable hours.

Two kinds of "determining factors" may be used: external or internal factors. "External" factors include the characteristics of the physical environment, e.g. soil, topography or weather conditions; of the fields, e.g. shape and size; of the farm, e.g. farming systems, equipment and manpower; or of the socio-economic and administrative environment : professional networks, extension services and municipality. While maps, remote-sensing shots, land registers or interpolation procedures provide geo-referencing for most factors related to the physical environment or field characteristics (Faivre et al., 2004), the last two groups of factors, those related to farms and the socio-economic environment, are available in various administrative databases which provide a location indication, most often the municipality the farm belongs to. For instance, Biarnès and Colin (2006) used the municipality to predict practices over the whole study extent since they found, by analysing field data samples, that weed control practices were well correlated with this factor (case B). In case A (Colbach, 2008; Angevin et al., 2002) the type and location of crop successions was considered as determined by the type of farm, defined by intensive vs. organic management, and by the farm and field sizes. Grid weather data were used by Maton et al. (2007a) to predict the spatial variability of sowing dates and by Leenhardt et al. (2004) to predict the spatial variability of irrigation dates (case C). Using an "external" determining factor consists of using a simple "If-then" allocation rule:

\section{If [external indicator(s)]}

then [cropping system (or element of it)]

However, sometimes no deterministic relation can be identified between a set of potential explanatory variables and the cropping systems or elements of them. This can be illustrated by Maton et al. (2007b), and Biarnès and Colin (2006). Maton et al. investigated determining factors of maize sowing and cultivar choice from geo-referenced databases (geographical information systems containing environmental characteristics of fields, spatially interpolated weather data series, or administrative databases containing farm characteristics collected from censuses). However, the variability of cropping systems could not be completely explained by these geo-referenced indicators. A combination of indicators led only to a probability of occurrence of a given cropping system. Similarly, Biarnès and Colin (2006) linked each municipality of the study extent to a given distribution of weed control practices.
The rule (1) becomes then a stochastic allocation rule:

If [external indicator(s)]

then [probabilities of cropping systems (or elements of them)

An "internal" factor corresponds to an element of the cropping system on which the choice of the other elements of this cropping system depends. For instance, Maton et al. (2007b) showed that the choice of cultivar earliness was partly determined by the sowing date, while Colbach (2008) and Angevin et al. (2002) used the crop succession to determine crop management choices. Internal factors are, by definition, not geo-referenced, and must be indirectly related to external indicators in order to predict the cropping system location. A second-order rule is thus needed:

\section{If [external indicator(s)]}

then [element(s) Eof the cropping system]

And

If [element(s) E of the cropping system]

then [cropping system]

The use of determining factors is therefore a way to overcome the difficulty of accessing data on cropping system variables. Identifying variables that can be used as determining factors of cropping systems can be done either by expertise from extension services or farm surveys, or by statistical analysis of databases. However, to specify cropping systems on all support units of the study extent, it is also necessary to be able to determine the modalities of these determining factor variables for all support units. Although determining factors are chosen among variables more easily accessible than cropping system variables, this can be problematic. For instance, in case A, cropping systems were recognised as determined by farm types, but the fields (support units) were not associated with a farm type. The solution was then to allocate randomly farm types to fields, while respecting certain spatial constraints such as isolation distances between crops.

To conclude, identifying determining factors of cropping systems can simplify the collection of cropping system information, but it is not always possible to obtain deterministic relations between easily accessible factors and elements of the cropping systems. In some cases, the access to the modalities of determining factors for all support units can also be difficult.

\section{CONCLUSION}

Sustainable development of regions and sustainable management of resources often require actions concerning land use. Sustainable solutions need to account for the coherence of technical choices within cropping systems and with their environment. However, very few agro-environmental studies account for both the coherence and the spatial variability of cropping systems. It was the objective of this article to review methods to describe and locate cropping systems within large and/or heterogeneous areas. This article focused particularly 
on 4 case studies differing in their objectives, but also their extent and support. Describing and locating cropping systems is required for diagnostic or scenario needs, where environmental models are often used to simulate cropping system impact. We noticed that extents and support units were constrained by the objective of the study and, if a model was required, by the process to be modelled. Choosing the extent, and the nature and size of support units is crucial because it conditions not only the precision of the location of cropping systems but also the precision of their description. Indeed, on a regional scale, it is not possible to represent all aspects of a cropping system. A simplification is necessary. The variables strictly necessary to describe the cropping systems must be chosen in accordance with the study objective and with the analysed processes in order to optimise the compromise between key variables and data availability. Collecting information to fill all support units with the modalities of such variables may be done using administrative surveys, remote sensing or expertise. However, it appears that, very often, such sources of information are not sufficient to fill all support units or to get all necessary cropping system variables. The use of determining factors, that are easily geo-referenced, is a way to overcome the difficulty of accessing data on cropping systems. However, it is not always possible to obtain deterministic relations between easily accessible factors and elements of the cropping systems, and sometimes, the access to the modalities of determining factors for all support units can also be difficult. A common feature of the methods presented here is their reliance on expertise or on detailed survey data. Expertise regarding agricultural practices is available in most countries from extension services. However, its reliability decreases when the size of the support unit or the time period increase. Furthermore, detailed surveys that are necessary either to describe cropping systems directly or to relate agricultural practices to their potential determining factors are rare and difficult to carry out for a single study. This calls for the development of adequate and routine land management practice monitoring.

Acknowledgements: The authors are grateful to Drs. V. Souchère, C. Thenail and B. Nicoullaud, and to the anonymous reviewers for their valuable comments, recommendations and corrections. We would like to thank M. R. Lesslie and D. Wallach for editorial advice in English. This study was conducted within the framework of the Cropping System network of the Environment and Agronomy Department of the French National Institute for Agronomical research (INRA).

\section{REFERENCES}

Angevin F., Colbach N., Meynard J.M., Roturier C. (2002) Analysis of necessary adjustements of farming practices, in: Bock A.K., Lheureux K., Libeau-Dulos M., Nilsagard H., Rodriguez-Cerezo E. (Eds.), Scenarios for co-existence of genetically modified, conventional and organic crops in European agriculture. Technical Report Series of the Joint Research Center of the European Commission, EUR 20394 EN, http://ipts.jrc.ec.europa.eu/publications/pub.cfm? $\mathrm{id}=1044$.

Angevin F., Klein E.K., Choimet C., Gauffreteau A., Lavigne C., Messean A., Meynard J.M. (2008) Modelling the impacts of cropping systems and climate on maize cross-pollination in agricultural landscapes: The MAPOD model, Eur. J. Agron. 28, 471-484.
Barson M., Lesslie R. (2004) Land management practices - why they are important and how we know this, in: National workshop on Land Management Practices: Information Priorities, Classification and Mapping, Canberra, pp. 1-9.

Beaujouan V., Durand P., Ruiz. L. (2001) Modelling the effect of the spatial distribution of agricultural practices on nitrogen fluxes in rural catchments, Ecol. Model. 137, 93-105.

Benoît M., Papy F. (1998) La place de l'agronomie dans la problématique environnementale, Dossier de l'environnement de l'INRA 17, 5362 .

Biarnès A., Colin F. (2006) Methodology for assessing the hydrological impact of weed control practices with a view to management of Mediterranean vine growing catchments, Int. J. Sust. Dev. World 9, 161-179.

Biarnès A., Rio P., Hocheux A. (2004) Analyzing the determinants of spatial distribution of weed control practices in a Languedoc vineyard catchment, Agronomie 24,187-196.

Bierkens M.F.P., Finke P.A., de Willigen P. (2000) Upscaling and downscaling methods for environmental research, Kluwer Academic Publishers.

BRS (2006) Guidelines for land use mapping in Australia: principles, procedures and definitions. A technical handbook supporting the Australian Collaborative Land Use Mapping Programme, Edition 3, Australian Government, Bureau of Rural Sciences, Canberra.

Chipanshi A.C., Ripley E.A., Lawford R.G. (1999) Large-scale simulation of wheat yields in a semi-arid environment using a crop-growth model, Agr. Syst. 59, 57-66.

Clavel L., Leenhardt D. (2008) Development of matrices to build scenarios of cropping systems distribution for integrated catchment assessment. A proposition for an irrigated area in southwestern France, in: Sànchez-Marrè M., Béjar J., Comas J., Rizzoli A., Guariso G. (Eds.), Integrating Sciences and Information Technology for Environmental Assessment and Decision Making, iEMSs 2008: International Congress on Environmental Modelling and Software, 4th Biennial Meeting of iEMSs, pp. 678-685.

Colbach N. (2008) How to model and simulate the effects of cropping systems on population dynamics and gene flow at the landscape level, Example of oilseed rape volunteers and their role for co-existence of GM and non-GM crops, submitted to Environ. Sci. Pollut. R.

Donet I. (1999) Étude sur l'interpolation de l'ETP quotidienne en points de grille. Report SCEM/SERV/AGRO, Météo-France, Toulouse.

Dunning J.B., Stewart D.J., Danielson B.J., Noon B.N., Root T.L., Lamberson R.H., Stevens E.E. (1995) Spatially explicit population models: current form and future uses, Ecol. Appl. 5, 3-11

Faivre R., Bastié C., Husson, A. (2000) Integration of VEGETATION and HRVIR into yield estimation approach, in: Gilbert Saint (Ed.), Proceedings of "Vegetation 2000, 2 years of operation to prepare the future", Space Application Institute and Joint Reasearch Center, Ispra, Lake Maggiore (Italy), pp. 235-240.

Faivre R., Leenhardt D., Voltz M., Benoît M., Papy F., Dedieu G., Wallach D. (2004) Spatialising crop models, Agronomie 24, 205-217.

Gomez E., Ledoux E. (2001) Démarche de modélisation de la dynamique de l'azote dans les sols et de son transfert vers les aquifères et les eaux de surface, C.R. Acad. Agric. Fr. 87, 111-120.

Hartkamp A.D., White J.W., Rossing W.A.H., van Ittersum M.K., Bakker E.J., Rabbinge R. (2004) Regional application of a cropping systems simulation model: crop residue retention in maize production systems of Jalisco, Mexico, Agr. Syst. 82, 117-138.

Heinemann A.B., Hoogenboom G., Faria de R.T. (2002) Determination of spatial water requirements at county and regional levels using crop models and GIS . An example for the State of Parana, Brazil, Agr. Water Manage. 52, 177-196. 
IPCC (2007) Climate Change 2007: Mitigation of Climate Change. Contribution of Working Group III to the Fourth Assessment Report of the Intergovernmental Panel on Climate Change, in: Metz B., Davidson O.R., Bosch P.R., Dave R., Meyer L.A. (Eds.), Cambridge University Press, Cambridge, United Kingdom and New York, NY, USA, 851 p.

Jouve P. (2006) La dimension spatiale des systèmes de culture : comparaison entre agriculture tempérée et agriculture tropicale, Cah. Agric. $15,255-260$.

de Juan J.A., Tarjuelo J.M., Ortega J.F., Valiente M., Carrion P. (1999) Management of water consumption in agriculture: A model for the economic optimisation of water use: application to a sub-humid area, Agr. Water Manage. 40, 303-313.

Lal H., Hoogenboom G., Calixte J.P., Jones J.W., Beinroth F.H. (1993) Using crop simulation models and GIS for regional productivity analysis, T. ASAE 36, 175-184.

Lançon J., Reau R., Cariolle M., Munier-Jolain N., Omon B., Petit M.S., Viaux P., Wery J. (2008) Élaboration à dire d'experts de systèmes de culture innovants, in: Reau R., Doré T. (Eds.), Systèmes de culture innovants et durables : quelles méthodes pour les mettre au point et les évaluer ? Educagri éd., Dijon, pp. 91-107.

Launay M., Guérif M. (2005) Assimilating remote sensing data into a crop model to improve predictive performance for spatial applications, Agr. Ecosyst. Environ. 321-339.

Le Bail M. (2005) Le bassin d'approvisionnement : territoire de la gestion agronomique de la qualité des productions végétales, in: Prevost $\mathrm{P}$. (Ed.), Agronomes et territoires : Deuxième édition des entretiens du Pradel, L'Harmattan, Paris, pp. 213-228.

Le Ber F., Benoît M., Schott C., Mari J.F., Mignolet C. (2006) Studying crop sequences with CARROTAGE, a HMM-based data mining software, Ecol. Model. 191, 170-185.

Ledoux E., Gomez E., Monget J.M., Viavattene C., Viennot P., Ducharne A., Benoit M., Mignolet C., Schott C., Mary B. (2007) Agriculture and groundwater nitrate contamination in the Seine basin. The STICS-MODCOU modelling chain, Sci. Total Environ. 375, $33-47$.

Leenhardt D., Trouvat J.L., Gonzalès G., Pérarnaud V., Prats S., Bergez J.E. (2004) Estimating irrigation demand for water management on a regional scale. I. ADEAUMIS, a simulation platform based on biodecisionnal modelling and spatial information, Agr. Water Manage. 68, 207-232.

Leenhardt D., Wallach D., Le Moigne P., Guérif M., Bruand A., Casterad M.A. (2006) Using crop models for multiple fields, in: Wallach D., Jones J., Makowski D. (Eds.), Working with crop models, Elsevier, pp. 209-248

Leteinturier B., Herman J.L., Longueville F.d., Quintin L., Oger R. (2006) Adaptation of a crop sequence indicator based on a land parcel management system, Agr. Ecosyst. Environ. 112, 324-334.

Louchart X., Voltz M., Andrieux P., Moussa R. (2001) Herbicide Transport to Surface Waters at Field and Watershed Scales in a Mediterranean Vineyard Area, J. Environ. Qual. 30, 982-991.

Mari J.F., Le Ber F. (2005) Temporal and spatial data mining with second-order hidden markov models, Soft Computing - A Fusion of Foundations, Methodologies and Applications, 406-414.

Martin P., Joannon A., Mignolet C., Souchère V., Thenail C. (2006) Systèmes de culture et territoires : cas des questions environnementales, in: Doré T., Le Bail M., Martin P., Ney B., Roger-Estrade J. (Eds.), L'agronomie aujourd'hui. Coll. Quae, Versailles.

Maton L. (2006) Représentation et simulation des pratiques culturales des agriculteurs à l'échelle régionale pour estimer la demande en eau d'irrigation. Application à un bassin versant maïsicole du sud-ouest de la France, PhD thesis, INPT, Toulouse.
Maton L., Bergez J.E., Leenhardt D. (2007a) Modelling the days which are agronomically suitable for sowing, Eur. J. Agron. 27, 123-129.

Maton L., Leenhardt D., Bergez J.E. (2007b) Geo-referenced indicators of maize sowing and cultivar choice for better water management, Agron. Sustain. Dev. (in press)

Meynard J.M., Doré T., Habib R. (2001) L'évaluation et la conception de systèmes de culture pour une agriculture durable, C.R. Acad. Agric. Fr. 87, 223-236.

Mignolet C., Bornerand C., Benoît M. (2001) Dynamique spatiale et temporelle de l'activité agricole dans le bassin de la Seine au cours des trente dernières années, C.R. Acad. Agric. Fr. 87, 99-109.

Mignolet C., Schott C., Benoît M. (2004) Spatial dynamics of agricultural practices on a basin territory: a retrospective study to implement models simulating nitrate flow. The case of the Seine basin, Agronomie 24, 219-236.

Mignolet C., Schott C., Benoit M. (2007) Spatial dynamics of farming practices in the Seine basin: Methods for agronomic approaches on a regional scale, Sci. Total Environ. 375, 13-32.

Moen T.N., Kaiser H.M., Riha S.J. (1994) Regional yield estimation using a crop simulation model: concepts, methods and validation, Agr. Syst. 46, 79-92.

Nordblom T., Hume I., Bathgate A., Reynolds M. (2006) Mathematical optimisation of drainage and economic land use for target water and salt yields, Aust. J. Agr. Resour. Ec. 50, 381-402.

Reca J., Roldan J., Alcaide M., Lopez R., Camacho E. (2001) Optimisation model for water allocation in deficit irrigation systems: I. Description of the model, Agr. Water Manage. 48, 103-116.

Rosenthal W.D., Hammer G.L., Butler D. (1998) Predicting regional grain sorghum production in Australia using spatial data and crop simulation modelling, Agr. Forest. Meteorol. 91, 263-274.

Rounsevell M.D.A., Annetts J.E., Audsley E., Mayr T., Reginster I. (2003) Modelling the spatial distribution of agricultural land use at the regional scale, Agr. Ecosyst. Environ. 95, 465-479.

Sebillotte M. (1974) Agronomie et agriculture. Essai d'analyse des tâches de l'agronome, Cah. ORSTOM 24, 3-25.

Sousa V. Santos Pereira L. (1999) Regional analysis of irrigation water requirements using kriging. Application to potato crop (Solanum tuberosum L.) at Tras-os-Montes, Agr. Water Manage. 40, 221233.

Stomph T.J., Fresco L.O., Van Keulen H. (1994) Land use system evaluation: Concepts and methodology, Agr. Syst. 44, 243-255.

Stoorvogel J.J. (1995) Integration of computer-based models and tools to evaluate alternative land-use scenarios as part of an agricultural system analysis, Agr. Syst. 49, 353-367.

Veldkamp A., Kok K., de Koning G.H.J., Schoorl J.M., Sonneveld M.P.W., Verburg P.H. (2001) Multi-scale system approaches in agronomic research at the landscape level, Soil Till. Res. 58, 129140.

Verburg P.H., Soepboer W., Veldkamp A., Limpiada R., Espaldon V., Mastura S.S.A. (2002) Modeling the Spatial Dynamics of Regional Land Use: The CLUE-S Model, Environ. Manage. 30, 391-405.

Verburg P.H., Veldkamp A. (2001) The role of spatially explicit models in land-use change research: a case study for cropping patterns in China, Agr. Ecosyst. Environ. 85, 177-190.

Yun J.I. (2003) Predicting regional rice production in South Korea using spatial data and crop-growth modelling, Agr. Syst. 77, 23-38.

Zimmermann A, Heckelei T., Pérez I. (2006) Working paper - Literature Review of Approaches to Estimate Structural Change, SEAMLESS Report No.16, SEAMLESS integrated project, EU 6th Framework Programme, contract No. 010036-2, http://www.SEAMLESS-IP. org, $45 \mathrm{p}$. 